\title{
BRAND CRISIS RESPONSE STRATEGIES: A TYPOLOGIES CONTINUUM
}

\author{
Bich Ngoc DO ${ }^{1 *}$, Tuan Phong NHAM(D2 2 \\ ${ }^{1}$ School of International Business and Marketing, University of Economics Hochiminh City, \\ Hochiminh City, Vietnam \\ ${ }^{2}$ School of Business Administration, VNU University of Economics and Business, Hanoi, Vietnam
}

Received 27 April 2020; accepted 13 January 2021

\begin{abstract}
This purpose of this study is to provide a spectrum to illustrate all applicable response strategies towards brand crisis management. A qualitative systematic method is adopted to review 128 relevant papers and synthesized in a brand crisis response typologies continuum. The findings were illustrated in the continuum which includes two main categories - primary response group with seven levels ranked lowest to highest by organizational involvement and responsibility, and secondary response group such as bolstering). This research result might enrich the current literature of brand crisis management which is fragmented and provide a clear guideline so that scholars and practitioners might track all pertinent solutions depending on low to high level of brands' effort towards handling problems. Recognizing the discrepancy among response strategies, marketers and branders can choose either singular or merged solutions shown in the map to form a timely response to brand crisis, which is the main factor to crisis response success.
\end{abstract}

Keywords: brand crisis management, brand crisis response strategy(ies), primary response strategies, and secondary response strategies.

JEL Classification: M1, M10.

\section{Introduction}

Brand crisis has long been recognized as an unexpected event which can vulnerably threaten firms' ability to maintain their business equilibrium (Lee \& Atkinson, 2019; Su et al., 2019). As investigated, nearly 75 percent of brands admitted at least one brand-fire exposure in a year and approximately $54 \%$ of them reported more than one crisis (Gumgum, 2018). This phenomenon is a consequence of the Technology and Internet proliferation and business environment being turned into fracture (Do et al., 2019) which can transform a simmering incident into fire in a blink of an eye.

A vast number of papers in crisis management draw attention to how firms practice response strategies to handle crises (Bundy et al., 2017). When a crisis occurs, stakeholders tend to explore possible causes and attributed responsibilities of related actors to set their evaluations (Lange \& Washburn, 2012). Those newly formed evaluation might alter stakeholders' attitude negatively towards brand equity and reputation particularly. In studies by Park (2017) and Liu et al. (2016, 2018), scholars proved that crisis response strategies might rescue brands from their reputation decline (Park, 2017). By forming the response actions in a timely manner, brands can reshape both cognitive and affective reactions of stakeholders and reduce negative effects from crisis (Do et al., 2019). In other words, speed and appropriate response strategy are key elements of crisis management.

When conducting a literature review among large databases including Emerald Insight, Science Direct, Taylor and Francis, and Springerlink, the results showed that scholars have begun to study this issue since 1990s; yet, this topic is increasingly focused to develop different response methods to counteract issues from 2010s to now. As mentioned in large-scale qualitative research of Bundy et al. (2017) and Wang and Laufer (2019, studies in this field tend to attach to real brand crisis cases in specific and different circumstances. Additionally, the results of those studies suggested list of brand crisis response strategies based on the occurrence and information from attached contexts. Hence, the research results were fragmented. In other words, there was little connection and relationship among those response strategies. Scholars and practitioners might find it challenging to track all pertinent strategies, identify the content and the differences of those

*Corresponding author. E-mail: bichdn@ueh.edu.vn

Copyright (C) 2021 The Author(s). Published by Vilnius Gediminas Technical University

This is an Open Access article distributed under the terms of the Creative Commons Attribution License (http://creativecommons.org/licenses/by/4.0/), which permits unrestricted use, distribution, and reproduction in any medium, provided the original author and source are credited. 
strategies. In response to the literature gap and the growing of brand crisis occurrence (Lee \& Atkinson, 2019, this study aims to explore the relationship of divergent brand crisis response strategies. The research questions are hence formed as following: (1) What are the available brand crisis response strategies? and (2) How can we illustrate and capture the relationship among strategies in a spectrum? The remainder of this study is elaborated as follows: Introduction to brand crisis, related theories and literature gaps; review method and the review results.

The research findings were presented in a spectrum which has contributed to current literature regarding brand crisis management. Prior papers examine different brand crisis response strategy in various distinctive circumstances. This continuum has ranged all available crisis response strategies according to different intensive degree so that both scholars and practitioners might track solutions effectively. Furthermore, scholars and practitioners might gain substantial benefit from this research, they can understand the clear distinction between strategies and to select the appropriate response in a timely manner.

\section{Brand crisis and the gaps}

\subsection{The phenomena of brand crisis}

Brand crisis is a source of uncertainty and change of organization (Hewett \& Lemon, 2019) as it happens unpredictably (Barton, 1993; Coombs, 2007a, 2007b; Bundy et al., 2017) and unexpectedly; such an event might result in negative consequences for organizations (Brown \& Ki, 2013; Wang \& Laufer, 2019). Precisely, brand equity (Ahluwalia et al., 2000; Dawar \& Lei, 2009; Dutta \& Pullig, 2011; Singh et al., 2020), brand reputation, and financial outcome (Barton, 1993; Hewett \& Lemon, 2019) might be negatively influenced by crisis as can be seen clearly from the following practical examples: Malaysian Airlines (2016), Audi China (2017), Uber (2017), United Airlines (2017), Korean Air (2018-2019), Dolce and Gabbana (2018 and 2019).

According to a study by James et al. (2011) and Kahn et al. (2013), crisis is a behavioral phenomenon which is constructed by actors who relate to the conflict and are influenced by it. Consumers, who perceive negative information from public and media, might generate negative perception on product and the brand trust (Jung \& Baeck, 2016). This perception spreads over like wildfire, from direct stakeholders - investors and customers to non-victim actors - media and general publics (Bundy \& Pfarrer, 2015; Lee \& Atkinson, 2019) under the influence of social media. Since communication barriers are blurred, brands and organizations might find it challenging to handle crisis and narrow negative information in a timely manner.

Converging from those definitions, the researchers synthesize four main characteristics of brand crisis as follows: uncertainty, brand's disease, contagion and butterfly effect. As such, brand crisis management is a process of brand efforts which minimizes the damages associated with crisis to avoid further corruption.

\subsection{Crisis response theories and literature gaps}

Post crisis communication is a central area of brand crisis management which aims to provide scientific evidence and arguments to generate decision-making during turbulent situations. Many papers in this field draw attention on two fundamental crisis response theories namely Attribution Theory (AT) and Situational Crisis Communication Theory (SCCT).

According to Attribution Theory, developed by Weiner (1985), individuals are motivated to search the causes when unexpected event happens; after assessing key actors and crisis responsibility, they evoke suitable emotions and feelings towards that stimuli and event (Coombs, 2007a). When it comes to SCCT, this theory, based on Attribution Theory ideas, is developed through a wide range of experimental research (Coombs \& Holladay, 1996, 2001, 2002, 2006; Coombs \& Jeans, 2014) to construct a framework including various clusters of response strategies. Precisely, each crisis type indicates a different level of organizational and customer attribution responsibility (Coombs \& Holladay, 2002; Bundy et al., 2017). The more responsibility customers have towards a brand, the more negative perception they construct (Lange \& Washburn, 2012; Cheng \& Lee, 2019; and Singh et al., 2020).

Crisis response strategy is defined as what and how brands and organisations communicate and act after a crisis occurs (Bundy et al., 2017; Singh et al., 2019). It is a mutual interactive relationship between two parties: one party-organization/brand seeks ways to escape from scandals and to encourage empathy of the public; another party - the public expects transparent explanation and justification for these problems.

Dating back from 1990s, numerous scholars have developed ranges of possible actions to help firms cope with brand crises. Prior papers by Benoit (1995) and Coombs (2006; 2007a) have set fundamental ground for brand crisis classifications and brand crisis response strategies list; those became signposts for several latter experimental research. However, those lists were conducted over a decade ago (1997 and 2007) which would not have captured up-to-date strategies suggested by latter scholars and failed to show the connection among response strategies. Moreover, upon screening the well-known databases mentioned in the introduction, it was found that this literature gap was hardly and insufficiently addressed. Therefore, it is essential to conduct a qualitative systematic review to provide a comprehensive synthesis solution to enrich the existing literature and practice.

\section{Research method}

Systematic qualitative review is adopted in this paper. Focusing on this particular research topic, systematic review allows researcher to systematically search the inter-disciplinary literature using online databases and to select the explicit papers (Pickering et al., 2015). Different from metaanalysis which focused on answering research questions by 
statistical methods, this method might help authors highlight the boundaries and the generalization of current literature; the expected result will provide multi-faceted and systematic paper which provides summary of the research field (Nikulina et al., 2019). Based on these reasons, systematic review is selected to fulfill the research aim.

To conduct this review, researchers performed an extensive research of published journals and books on online databases following a series of conditions. Firstly, this review will primarily cover the time period from 1990 to 2019 (with a few exceptions such as foundation theories), as brand crisis management has received research intention since then, to provide a comprehensive and updated picture of consumer behavior towards organizational response strategies. Secondly, the review will concern publications from four outstanding databases including Emerald Insight, Science Direct, Taylor and Francis, and Springerlink.

In order to select papers for this systematic study, three stages were conducted:

(1) Searching and identifying papers from online scientific databases;

(2) Screening titles and abstracts to select relevant articles to topic;

(3) Selecting eligible papers to conduct systematic review through in-depth review and narrative synthesis.

In Stage I, the following online databases were used: Science Direct, Emerald Insight, Springerlink, and Taylor and Francis. The adopted keywords to screen articles included "brand crisis management", "crisis response strategy/(ies)", "crisis management". In this stage, authors set a limitation in advanced search; only research articles were accepted in this systematic review. In total, 882 papers were found in this stage.

In Stage II, titles and abstracts of 882 papers were screened to determine the relevance to research topic resulting in 453 papers which remained.

In Stage III, all articles were screened in-depth in full to short-list eligible papers. The final list consisted of 128 papers from four reputational publishers mentioned in Stage I. The selected articles are required to meet the following criteria: papers mentioned brand crisis response strategies (brand crisis management) in literature review or findings, papers were research paper, the peer-reviewed articles are from reputable journals in chosen databases, the articles are written in English.

\section{Research result}

\subsection{Quantitative review result}

Figure 1 shows that a majority of brand crisis management articles are published on Science Direct and Springerlink. The other two publishers have had a quite comparable number of researches. It is noteworthy that brand crisis management started to appear in research in the 1990s; however, the number of research papers has grown rapidly since 2010. In the last four years, this topic has received extraordinary attention and publication with approximately half of total reviewed papers. From this statistical result, it can be said that brand crisis management and brand crisis response strategy are contemporary topics to explore and investigate.

\subsection{Qualitative review result - typologies continuum}

Authors divided brand crisis response strategies into 2 main categories: (1) primary response and (2) secondary response. The primary response indicates mandatory actions which focus and respond to the brand crisis mandatorily, those actions can be performed individually or integrated with secondary strategies to maximize the effects. On the other hand, secondary response refers to the additional strategy or activities alongside primary response to raise positive stakeholders' attitude regarding brand image such as Corporate Social Responsibility. Different from primary response, secondary response can be conducted at any time of the business lifetime.

Therefore, Figure 2 (Appendix) illustrates the research results as a continuum of brand crisis response strategies. There are seven levels in primary response group ranging from no response or limited efforts to superior efforts in dealing with brand crisis. The following section presents explanation and discussion for each level in the brand crisis spectrum.

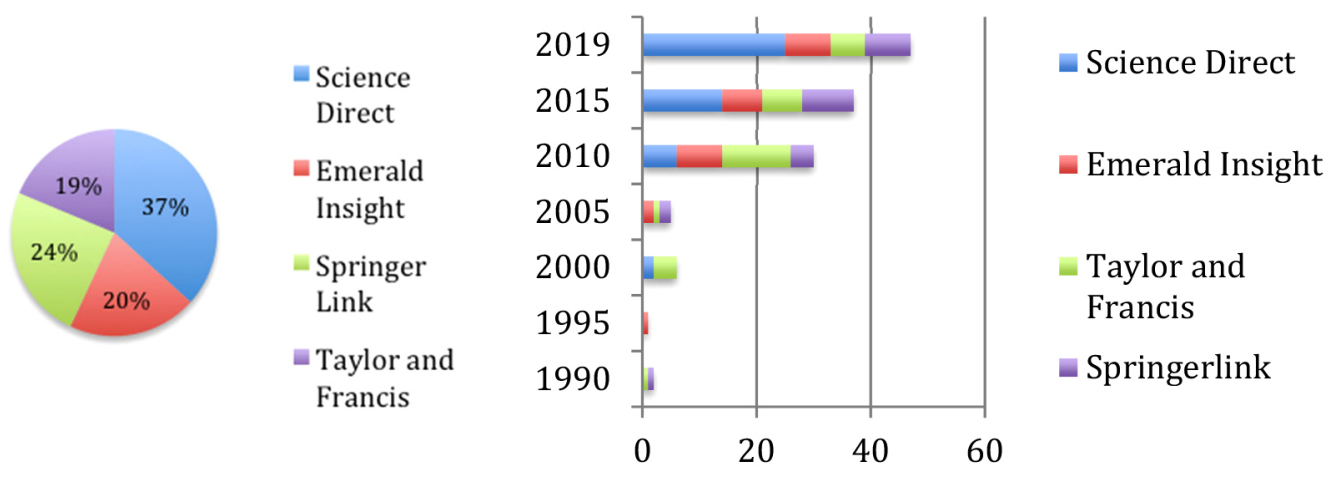

Figure 1. Distribution of papers by years and publishers (source: author's analysis) 


\subsubsection{Primary cluster - defensive brand crisis response strategy}

As cited in many papers, defensive strategies show low level of organizational responsibility (Chun-ju et al., 2013; Bowen et al., 2017) towards tackling problems. As such, the firms would intend to deny the existence of crisis or to avoid and to scapegoat any attached associations to crisis (Kim \& Park, 2017; Bundy et al., 2017). Therefore, in Figure 2, authors placed defensive as a house-strategy covering all strategies from "no comment" to "accept minimum responsibility".

\section{"No comment"}

The term "no comment" and "no response" are used interchangeably to reflect no reaction and stay silent towards accusation and brand crisis. Using this pathway, firms would not show any correlation and implement any communication response to tackle problems (Bradford \& Garrett, 1995; De Blasio \& Veale, 2009; Vafeiadis et al., 2019). There was a large number of firms engaging with this method having received accusations (83/127 cases) (Lamin \& Zaheer, 2012); however, silence in some cases caused crisis wire-spread and crisis spill over to other parts of the business (Do et al., 2019). Therefore, in brand crisis response continuum, "no comment" is categorized as lowest level of organizational involvement and responsibility towards solving brand crisis.

While conducting this review, authors found that there exists limited amount of study research about "silence response strategy" with following gaps: (1) When should brands use no comment to respond to brand crisis, (2) How long should brands stay silent, (3) The effectiveness of no comment response strategy in different culture contexts and crisis typologies. Further studies might be conducted to fill these gaps.

\section{"Simple deny"}

"Simple deny", some other articles named it as flat deny (Johar et al., 2010), is a strategy mentioned in most studies about brand crisis response (Ware \& Linkugel, 1973; Benoit, 1997; Coombs, 2006, 2007a, 2007b; Standop \& Grunwald, 2009; Miller \& Littlefield, 2010; Richard et al., 2017; Singh et al., 2019). Using deny strategy, brands reject all responsibility (Souiden \& Pons, 2009; Claeys \& Cauberghe, 2014) and show low organizational concerns (Rouvaki et al., 2014) in relation to the problems. Among crisis typologies, this type shows no or lowest firms' responsibility towards solving the issue. While denial is a must-use method when negative rumors appear which threatens brands' reputation (Johar et al., 2010) especially with the example of Oprah in the US or when firms' integrity is threatened (Singh et al., 2019); in the meta-analysis of Arendt et al. (2017), this strategy was found least successful with $62 \%$ failure. Other study of Bowen and Zheng (2015) on Toyota denial response showed negative effects on media coverage and tone to reshape audiences' perception in Japanese context. Thus, gaps for future research remain due to inconsistent findings; for example, in which context can denial be used as a single strategy or is it required to combine with other strategies to leverage successful rate; or examining the effectiveness of denial strategy in different cultural contexts.

\section{Win a sympathy}

The brands aim to minimize effects and refuse attachment with brand crisis by persuading public empathetic emotions resulting from trust in brands' innocence. Following this signpost, the idea was firstly developed by Benoit (1995), some brands can either implement provocation strategy or defeasibility when they prove to the public that brands' issues were caused by hostility actions and blur organisational involvement to crisis event such as unintentional accident (Benoit, 1995; Grundy \& Moxon, 2013) and rebuttal (Johar et al., 2010). In another study of Coombs (1995), brands might also let the public understand how firms are suffering from the problem of trying to win the heart of stakeholders. Although scholars suggested different strategies mentioned in this section, all of them focus on lenient actions to influence stakeholders' affective state to reach the stage of empathy towards brands' mistakes. Compared to "simple deny", "win sympathy" shows more positive intention in blurring occurred crisis; however, compared to "distance strategy", this group expresses lower level of organizational responsibility in investigation and public announcement to scapegoat or attack accusations. Hence, authors placed "win sympathy" as having lower organizational efforts towards brand crisis than "distance strategy".

\section{Inclusive strategy of win a sympathy - refuse and avoiding \\ Three response groups - "no comment", "simple deny"} and "win a sympathy" posed the organizational refusal for brand crisis. Following idea of Coombs and Holladay (2012), Kim et al. (2016), they explained "refuse" strategy by ignoring the problems or win an emotional empathy from the stakeholders. In the same vein with these researchers, Wang et al. (2015) also mentioned "avoiding' holds the same intention with "refuse". Hence, authors allocate refuse and avoiding strategy would consist of these three-mentioned groups above.

\section{Distance strategy}

In contrast to earlier findings - "win a sympathy" strategy consists of a range of actions which mainly use audiences' empathy to blur the seriousness of brand crisis; however, distance strategy focuses on decoupling brands from burden by cognitive influence (Coombs \& Laufer, 2018). It shows higher level of brand efforts and involvement towards the occurred issue by serious investigation and planning to decouple crisis from organization compared to "win a sympathy". With the same idea with Coombs, later researchers including Coombs and Holladay (2012) and Kim et al. (2016) introduced "refute" as a range of actions to challenge the public to accusations. 
Therefore, authors categorized "refute" in the same column with distance strategy.

In distance strategy, there are several responses suggested by prior scholars. Table 1 summarized key strategies in this category as follow.

RyanAir had adopted this crisis response strategy in recent discrimination crisis during the end of 2018. Shifting the responsibility to police by posting a statement as "We are aware of this video and reported this matter to Essex police" and set a long distance from the burdensome lead to a tremendous boycott wave in social media. This case study is one of recent firm which still adopt this typology in dealing with brand crisis. Additionally, in recent experimental study of Brown and White (2010), there was no significant differences when using mentioned strategies such as differentiation, scapegoat. Responding to inconclusive statements, authors decided to place nine response strategies in the Table 1 belonging to distance strategy group, as they guided brands show little involvement, low responsibility and medium level of efforts towards brand crisis management.

\section{Accept responsibility but minimization}

Different from "distance strategy", brands adopted "accept responsibility but minimization" when it recognizes the existence of brand crisis, somewhat accepts the responsibility but strives to minimize the involvement. Authors found seven strategies in this group including: Minimization,
Diminishment, Excuse, Justification, Transcendence, Yes... but strategy, Individual-casual response/Individual-group disassociation and Act-essence Dissociation.

Minimization is act to reduce the crisis' seriousness (Benoit, 1995; Hansen et al., 2018) and place the event in more positive environment (Grundy \& Moxon, 2013). Instead of denying or directly refusing by setting a distance from problems, firms address the existence of problem but turn issues to be less severe than they actually become (Richards et al., 2017). Applying this method, National Football League (NFL) has successfully framed this issue becoming inconsequential to reduce the publics' offensiveness. It can be said that minimization does not show direct refusal; the firm acknowledges the problems but shifts the public's attention beyond the current circumstances. Hence, authors categorized it into this cluster.

Transcendence, a type of apologia, refers to transforming the cognitive thinking of the public (Ware \& Linkuge, 1973; Hearit, 1997) which might neutralize the public's negative perception (Huang, 2006). It happens when brand might broaden the context of brand crisis (Grundy \& Moxon, 2013), or reframe the facets of an issue in more abstract interpretation (Huang, 2006; Coombs et al., 2010; Singh et al., 2019) to turn a problem into that of less seriousness. If successful, audiences might develop a new angle of interpretation as a new light through their evaluation. The problems, consequently, can be perceived as less damaged as they turn out to become.

Table 1. Distance strategy group (source: authors' collection)

\begin{tabular}{|c|c|c|}
\hline Strategy & Explanation & Source \\
\hline Differentiation & $\begin{array}{l}\text { Differentiation refers to transformative actions which separate brands' } \\
\text { involvement and responsibility from the brand crisis context by } \\
\text { changing audiences' meanings by range of planned activities. }\end{array}$ & $\begin{array}{l}\text { Ware and Linkugel (1973), Benoit } \\
\text { (1997), Ihlen (2002), Gundy and } \\
\text { Moxon (2013) }\end{array}$ \\
\hline Ceremonial action & $\begin{array}{l}\text { Ceremonial action refers to ranges of activities which address the key } \\
\text { issues to alter stakeholders' impression from accusations. When crisis } \\
\text { occurs, stakeholders construct knowledge from media coverage; hence; } \\
\text { main tactic for ceremonial strategy is informing messages on media } \\
\text { coverage intensively to shift attention away. }\end{array}$ & Zavyalova et al. (2012) \\
\hline Attack accuser & $\begin{array}{l}\text { This method aims to confront brand crisis by reducing the accusers' } \\
\text { reliability by authoritative actions such as legal sue. }\end{array}$ & $\begin{array}{l}\text { Benoit (1997), Coombs (2006), } \\
\text { Coombs (2007b), Grundy and } \\
\text { Moxon (2013), Ma and Zhan } \\
(2016)\end{array}$ \\
\hline Vilify the accuser & $\begin{array}{l}\text { Vilify the accuser is quite similar to attack accuser. This strategy aims } \\
\text { to reduce credibility of accuser using wide range of offensive actions } \\
\text { instead of sole argument. However, it is better applied for high identity } \\
\text { customers. }\end{array}$ & Johar et al. (2010) \\
\hline Scapegoat & \multirow{2}{*}{$\begin{array}{l}\text { Scapegoat and Inoculation refers to provide argument to shift the } \\
\text { involvement from brand. Brands' manager publishes series of logical } \\
\text { explanation to blame other people who have somewhat attachments } \\
\text { with organization. While, inoculation presents argument to shift the } \\
\text { problem away (out of organization) before accusation hits. }\end{array}$} & $\begin{array}{l}\text { Coombs (2007b), Johar et al. } \\
\text { (2010), Grundy and Moxon (2013) }\end{array}$ \\
\hline Inoculation & & $\begin{array}{l}\text { Coombs (2007b), Johar et al. } \\
\text { (2010), Grundy and Moxon (2013) }\end{array}$ \\
\hline $\begin{array}{l}\text { Decoupling (with/ } \\
\text { without CEO) }\end{array}$ & $\begin{array}{l}\text { This strategy focuses on setting a distance from the problem using } \\
\text { logical arguments in order to persuade public audiences. Some other } \\
\text { articles named this method as scapegoat. }\end{array}$ & $\begin{array}{l}\text { Lamin and Zaheer (2012), Laufer } \\
\text { et al. (2017) }\end{array}$ \\
\hline Defiance & $\begin{array}{l}\text { This strategy refers to attack accuser as it aims to contest and challenge } \\
\text { the accusation with cognitive evidences. }\end{array}$ & Lamin and Zaheer (2012) \\
\hline
\end{tabular}


Diminishment actions accept low amount of involvement and little responsibility towards issues (Coombs \& Holladay, 2001; Lin et al., 2011; Ma \& Zhan, 2016) by reducing the perceived seriousness of the public (Singh et al., 2019). In other words, this tactic strives to illustrate evidence-based to protect their reputation (K. Sano \& H. Sano, 2019). According to several papers of Coombs (2006b, 2007a), Richards et al. (2017) and Kumar et al. (2019) diminishment strategy consists of two tactics one is excuse and the other is justification. While excuse strategy aims to limit organizational responsibility by either denying firms' intention of doing harmful actions or showing firms' inability to control the situation (Coombs, 2007b). Firms can officially announce range of statements to excuse the limitation of controllability towards event occurrence (Huang, 2006; Standop \& Grunwald, 2009). The justification, another type of diminishment, reduces the perceived damages caused by crisis, which means the firm has performed less harmful damage than the public had perceived (Richards et al., 2017). Even though firms adopt either excuse or justification, they indirectly recognize the existence of brand crisis without denial attention but show greater effort to draw brighter picture to persuade the public compared to "win a sympathy" group.

Yes...but strategy, is explored by Johar et al. (2010), provides some arguments which downplay the outcomes of brand crisis in order to blur the consequences in the eyes of the public. It can be said that this strategy is renamed and quite similar with justification and excuse strategy developed by Coombs (2007a, 2007b).

Applying the idea of "Individual-casual response", an organization accepts the crisis existence but minimize influences by announcing that crisis happened just because of one-individual mistake (An et al., 2010). Similarly, Hearit (1997, 2006; cited in Coombs et al., 2010) suggested a similar method called "individual-group disassociation"; this strategy draws public attention on individual or one small group's responsibility for the problem but organisation (Custance et al., 2012). Whether it is one individual or one group, these two strategies focus on minimizing the organizational involvement by transferring guilt then separating these individuals or groups from organization.
Last but not least, organizations adopt "act - essence dissociation" when they admit failure as an act of the brand; however, the failure does not represent the whole nature of organization (Custance et al., 2012). Although firms concede the existence of brand crisis, they prefer to provide further explanations to reduce the publics' assumptions. These explanations could be an excuse or a justification for a given fact. Hence, authors categorized "act/essence dissociation" as a part of group "accept but minimize effects".

Inclusive strategy of accepting responsibility but minimization - fighting, refute and reduce offensiveness

In the response strategies continuum, fighting, refute and reduce offensiveness response consists of both "set a distance" and "accept responsibility but minimization" as it analyzes the crisis situation, addressing the jobs to be done in order to maintain a positive attitude and lessen negative effects during crisis (Wang et al., 2015; Baghi \& Gabrielli, 2019). While "set a distance" strives to help organization counteract the crisis by setting no relation, "accept but with limited responsibility" aims to minimize the accusation yet admit the mistake to maintain positive public's attitude. Regarding refute strategy, his strategy was firstly developed by Coombs and Holladay (2012) and then largely generalized by latent research. Brand recognized the brand crisis as an accusation; hence, they strived to distance from crisis by series of arguments (Kim et al., 2016; Ismail et al., 2018; Sawalha, 2019). Hence, authors placed "fighting and refute" as method which might include two mentioned strategies, being "set a distance" and "accept responsibility but minimization".

\subsubsection{Primary response strategy - accommodative brand crisis response strategy}

Accommodative strategies guided branders to intentionally admit and accept the responsibility (Bundy et al., 2017; Jiménez et al., 2020) so that corrective actions might be offered. Several studies have suggested a wide range of terms to indicate high responsibility of organizations towards handling crisis. Table 2 presented below illustrates similar ideas from prior authors.

Although each scholar named their strategy differently; however, all mentioned types' explanation are similar to accommodative ideology. Therefore, authors placed

Table 2. Accommodative strategies explanation (source: authors' collection)

\begin{tabular}{|l|l|}
\hline \multicolumn{1}{|c|}{ Brand crisis response } & \multicolumn{1}{c|}{ Key explanations } \\
\hline Concession & $\begin{array}{l}\text { Firms accept the responsibility (Standop \& Grundwald, 2009) and are open to some improvements } \\
\text { (Huang, 2008). }\end{array}$ \\
\hline Accommodative & Accommodation posed high organizational involvement in solving crisis (Richards et al., 2017). \\
\hline Come and clean & $\begin{array}{l}\text { Be truly transparent. Firms show regret attitude and accept the fault by apology or mortification } \\
\text { (Johar et al., 2010). }\end{array}$ \\
\hline Reform & $\begin{array}{l}\text { Reform strategy is applied when crisis is addressed, and brands offer some degree of changes or } \\
\text { improvement (Kim et al., 2016; Cwalina \& Falkowski, 2018). }\end{array}$ \\
\hline Acknowledge and Rebuild & $\begin{array}{l}\text { Organisations attempt to admit the faults and detect the remedy to solve the problem for both } \\
\text { brands and stakeholders (Coombs, 2007a, 2007b; Singh et al., 2019). }\end{array}$ \\
\hline
\end{tabular}


accommodative, concession, come-and-clean, reform, and acknowledgement and rebuild as house-strategyterm covering from "accept responsibility (organizational level)" to "improvement".

\section{Accept responsibility (non - improvement)}

The sixth level in brand crisis response continuum is accepting responsibility at organisational level but fail to show the improvement activities towards brand crisis. Different from the next cluster - accept with improvement, although firms show full acceptance for brand crisis and express regret attitude to please the public; they might limit the corrective actions to amend the affected audiences.

Following this pathway, studies of Pfarrer et al. (2008) and DiStaso et al. (2015) had sythesized two types of brand crisis management stages consisting three levels each, one is Acknowledgement - Express Regret - Apology and the other is Information - Sympathy - Apology for firms to deal with brand crisis. Although these flows are named differently, their ideas implied are quite analogous.

Level 1, Acknowledgement or Information, it is crucial to understand that timely information might help firms avoid further harm and contribute to overall effort to recover brand image and reputation (Bundy \& Pfarrer, 2015; Coombs, 2015; Zavyalova et al., 2012). After addressing causes leading to brand crisis, acknowledgement refers to organizational explanation (Pfarrer et al., 2008) to update real-time information for stakeholders so that the audiences might be less aggressive when compared to no response strategy. Study of Claeys and Cauberghe (2012) has proven the effect of latest information and organizational acknowledge statement in reducing public's offensiveness. By accepting the involvement in wrongdoings, acknowledgement or information belong to "accept responsibility without improvement" group. Level 2, Express Regret or Sympathy, both terms refer to brands' response influencing stakeholders' affective state. While sympathy strategy focuses on victim's requirements (Pfarrer et al., 2008; Bundy et al., 2017) by being attentive stakeholders' feedbacks and announcing appropriate information to gain sympathy; express regret is considered an organisational response which shows repentance after circumspect investigation (Coombs \& Holladay, 2008; DiStaso et al., 2015). In the same line with Bundy et al. (2017) and DiStaso et al. (2015), researchers agree that express regret and sympathy is somewhat in the middle between discovery phase and apology phase in accommodative continuum. Since the brands are not required to offer any amends in this level, hence, it is categorized in this group. Level 3, Apology is apparently introduced by Ware and Linkgel (1973) in a criticism context yet Benoit (1995) set the early stone to propose apology as a strategy to respond to brand crisis. Apology, which is a part of accommodation (Lamin \& Zaheer, 2012; Lee et al., 2019), is firms' response to ask for stakeholders' and public forgiveness (DiStaso et al., 2015 and Lee et al., 2019). According to
Zhu et al. (2017), apology is one of the highest level of response strategy since brands can either send the deepest and sincerest apology to affected respondents or apology with compensation to blur public irritation. Therefore, researchers placed apology in merger position between "accept responsibility without improvement" and "improvement" group.

Different from individual-causal response in "accept but minimization" group, organizational-causal response indicates high level of responsibility and self-treatment when brand crisis occurs. Conceptualizing from Iyengar's (1991) classification, this strategy guides firms to admit crisis antecedents originated from organization itself or larger external environment (cited in An et al., 2010). At this point, brands can choose either to accept the accusations only or to revise the entire system and policies to avoid any further duplication (An et al., 2010; Coombs \& Tachkova, 2018). Hence, researchers placed organizational-causal response in merged position between "accept responsibility without improvement" and "improvement" group.

\section{Improvement}

The top-level group in primary response category is improvement; it refers to organizational corrective actions to compensate affected people, which is considered the highest level of responsibility and self-treatment (Zhu et al., 2017) compared to other groups. Prior studies have proposed some strategies to suggest the signpost for brands when it comes to amendment. Precisely, these strategies can be arranged as three-levels starting with forced compliance or involuntary/forced recall, then voluntary compliance or voluntary recall and super efforts at highest level. Whilst, forced compliance or involuntary/ forced recall indicates that brands would recall the faulty product as a third party's order such as regulatory agencies (Siomkos et al., 2010; Claeys \& Coombs, 2020). The voluntary recall/compliance indicates the organizational willingness to recall or fix faulty products before any governmental forces (Vassilikopoulou et al., 2009). Both types of methods share a key feature being a recall of harmful product; however, these are different from organizational treatment intention. Therefore, researchers decided to place the former in lower responsibility and effort in improvement than the latter.

Expressing superior efforts and responsibility to solve brand crisis outcomes, companies strive to fix the failures, to compensate tangibly or intangibly upon organizational decision and to try hard to communicate a positive brand image post crisis might be named "super efforts" (Siomkos et al., 2010; Rouvaki et al., 2014), "compensation" (Coombs, 2007b; Claeys \& Coombs, 2020), "offer amends" (Pfarrer et al., 2000). Those strategies suggest firms to provide sequential corrective actions to amend and compensate affected audiences as a way to completely terminate the crisis spill-over and win public sympathy. It means using "human-oriented solution" for "human-problem". 
Turning to other studies, instead of separate organizational improvement into sub-groups, other authors summarized brand's actions in accepting responsibility and preventing reoccurrence with improvement campaign such as conciliation (Hearit, 1997, 2006), correction (Benoit, 1997; Dutta \& Pullig, 2011; Liu et al., 2018), added value actions (Alonso-Almeida \& Bremser, 2013; Semerciöz et al., 2015), compromise (Wang et al., 2015). Although fore-mentioned strategies were named distinctively in prior studies, the implications for branders and brand managers are similar and compatible.

\subsubsection{Secondary response strategy}

Secondary response strategies consist of actions that aim to support the main crisis response strategies in diminishing negative attitudes of users generating from brand's problems. The main objectives of secondary brand crisis response strategies are distracting the public's attention on brands' issue and enhancing stakeholders' relationships by reminding/informing the public about "good brand image" by several past good actions or conducting wide range of public relation activities. Based on this perception, authors categorized: bolstering, ingratiating, polishing the halo, and proactive actions into this type.

\section{Bolstering}

According to Ihlen (2002) and Coombs et al. (2010), organizations perform bolstering strategy using brand ambassadors as speakers who convince the public that the brand's behavior is good following their perception. It means brands might shift audience's attention beyond crisis events (Massey \& Larsen, 2006; Kriyantono \& McKenna, 2020) towards the positive and philanthropic activities that posed brand overall identity. Some scholars such as Coombs (2007a), and Kim and Sung (2013) agreed that this strategy is suitable to recover brand reputation during and primarily post-brand-crisis. There are two reasons leading to this outcome; firstly, negative emotions of audiences resulted in brand crisis by triggering their attention (Baghi \& Gabrielli, 2019; Jin, 2013), bolstering strategy could diminish their negative emotion as a way to enhance audiences' attention towards other information of brand crisis response strategy (Lin et al., 2011). Secondly, with value-related crisis, bolstering strategy emphasizes on stakeholders' connections to the firms (Gistri et al., 2019; Sohn \& Lariscy, 2015); therefore, it can amplify the negative effect of brand crisis (Vanhamme et al., 2015) and play a role as a buffer in crisis time (Hegner et al., 2016). Yet, there are evidences showing the adverse effect. In cases where customers prefer and are loyal to a certain brand, brand crisis tends to adversely affect them more than it would do to other nonchalant customers (Shim \& Yang, 2016).

This strategy can be conducted at any-time of business life-time to reinforce favourable publics' attitude and relationships; therefore, it is categorized as secondary brand crisis strategy.

\section{Ingratiation}

Ingratiating strategy prioritises centralization of stakeholders. The organisations might either remind stakeholders of past good works (Coombs, 2006a; Richards et al., 2017) or praise stakeholders by thanking for their supports (Coombs, 2006b; Xu \& Li, 2012). In some research such as Liu et al. (2015), Hegner et al. (2016), Richards et al. (2017), ingratiation is a part of bolstering strategy since it is similar to promotional Corporate Social Responsibility - CSR (part of public relation) activities - enhancing brand's connection with small group of brand's citizenship. However, Arendt et al. (2017), conducted a qualitative meta-analysis, suggested that ingratiation includes bolstering. Despite these arguments, in this study, authors can see clearly that both strategies put emphasis on the relationship with their stakeholders by maintaining positive traits and praising citizenship. These aims can be performed at any time in business life-cycle; hence, ingratiation belongs to secondary response group.

\section{Polish the halo}

When choosing the accommodative response strategy such as apology, brands need to boost response effects by polishing their brand image, especially to less-identified customer (Johar et al., 2010). Using advertising and public relation, these tactical actions might influence the unaffected general public and they will use their favor to polish a new favourable image on others in the society (Kim \& Atkinson, 2014). This method is able to prevent crisis spillover from competitors in the same industry (Einwiller \& Johar, 2007; Bundy et al., 2017). Therefore, polish the halo is used for firms to protect themselves from external spillover, not necessarily an actual brand crisis. It is classified as secondary brand crisis response strategy.

\section{Proactive}

Proactive strategy focuses on extending marketing and sales effort (Ang et al., 2000; Alonso-Almeida et al., 2013; Semerciöz et al., 2015; Claeys \& Coombs, 2020). Brands might introduce a new product and focus marketing campaign for launching this new product. The media coverages about the new product might distract publics' attention from burden (Pearce \& Micheal, 2006; AlonsoAlmeida et al., 2013; Singh et al., 2019). Some empirical research in the tourism and hospitality industry proved the effectiveness of this proactive strategy in recovery phase (Okumus \& Karamustafa, 2005; Semerciöz et al., 2015). Turning sales into new segments is examined to be effective to recover financial negative outcomes from crisis (Alonso-Almeida \& Bremser, 2013). Yet, launching new product immediately after brand crisis occurs could be seen as organizational suicide. Since the public's madness might negatively influence revenue in introduction phase.

In fact, brands can launch new model when their current model reaches saturation phase (Kotler et al., 2018). Hence, these are considered supportive tactics for primary brand crisis response strategy post-crisis. 


\section{Conclusions and limitations}

This study has reviewed the brand crisis response strategies which are under examination in prior research to propose a coherence response continuum (in Figure 2). Some notable findings in the continuum will be elaborated below.

Drafting from Figure 2, brand crisis response strategies were grouped into seven levels in one spectrum. The primary response strategies and secondary response strategy were classified depending on varying levels of organizational responsibility and efforts in brand crisis management.

Firstly, the primary response strategy is mandatory responses conducted only once brand crisis has occurred. This category consists of two sub-groups which are defensive and accommodative. Regarding the defensive cluster, five levels ranked from low to high responsibility and efforts are presented. These are "no comment", "simple deny", "win a sympathy", "Distance strategy" and "accept but minimization". When it comes to the accommodative cluster, two groups were found as "accept responsibility without improvement" and "improvement". These methods direct brands to show high level of responsibility and correction towards brand crisis instead of turning back on the public as extreme defensive strategy like 'no comment' and "simple deny".

Secondly, the secondary response might be conducted at any time of a business lifecycle and support primary response strategy. It includes "bolstering", "ingratiating", "polish the halo" and "proactive". Prior fundamental research of Benoit (1995) and Coombs (2007a) has provided a list of possible responses ranging from denial to corrective and weight mentioned strategies as equivalent to primary responses in handling brand crisis. However, our suggestion is different from their research when separating these four strategies from primary group. Since these responses focus on activities such as using advertising, corporate social responsibility to blur negative perception; yet, organizations might perform it at anytime to increase trust and positive public affection. Therefore, it is reasonable to split these four strategies into a new cluster - secondary response.

This new continuum has contributed to current literature regarding brand crisis management. Firstly, previous studies have investigated different responses strategies based on distinct context. It leads to the fragmentation in crisis management topic in particular (Bundy et al., 2017). The brand crisis continuum has ranged all available crisis response strategies into levels in one spectrum so that both scholars and practitioners might track solutions effectively. Secondly, prior studies only present lists of strategies without adequate comparison. The continuum attempted to provide a different perspective on crisis response strategies classifications when dividing into two distinct categories: primary and secondary. Based on this spectrum, scholars and practitioners might gain a big-picture understanding and clear distinction between strategies. According to Do et al. (2019), immediate first-hand information after crisis might strongly affect audiences' perception. Thus, using this result can save wasted time for practitioners to research and provide an appropriate response in a timely manner. Although this research has covered available research published on four outstanding databases, it has its own constraints. Hence, future research should extend the scope of database so that the continuum can reach higher sophistication.

\section{Acknowledgements}

Authors would like to send gratitude for Mr. Le Nam Long, Head of Creative and Production at Shopee Vietnam for his valuable comments.

\section{References}

Ahluwalia, R., Burnkrant, R. E., \& Unnava, H. R. (2000). Consumer response to negative publicity: the moderating role of commitment. Journal of Marketing Research, 37(2), 203-214. https://doi.org/10.1509/jmkr.37.2.203.18734

Alonso-Almeida, M. del M., \& Bremser, K. (2013). Strategic responses of the Spanish hospitality sector to the financial crisis. International Journal of Hospitality Management, 32, 141-148. https://doi.org/10.1016/j.ijhm.2012.05.004

An, S.-K., Park, D.-J., Cho, S., \& Berger, B. (2010). A cross-cultural study of effective organizational crisis response strategy in the United States and South Korea. International Journal of Strategic Communication, 4(4), 225-243.

https://doi.org/10.1080/1553118X.2010.515543

Ang, S. H. A., Leong, S. M., \& Kotler, P. (2000). The Asian apocalypse: crisis marketing for consumers and businesses. Long Range Planning, 33(1), 97-119.

https://doi.org/10.1016/S0024-6301(99)00100-4

Arendt, C., LaFleche, M., \& Limperopulos, M. A. (2017). A qualitative meta-analysis of apologia, image repair, and crisis communication: Implications for theory and practice. Public Relations Review, 43(3), 517-526.

https://doi.org/10.1016/j.pubrev.2017.03.005

Baghi, I., \& Gabrielli, V. (2019). The role of crisis typology and cultural belongingness in shaping consumers' negative responses towards a faulty brand. Journal of Product \& Brand Management, 28(5), 653-670. https://doi.org/10.1108/JPBM-03-2018-1806

Barton, L. (1993). Crisis in organizations: Managing and communicating in the heat of chaos. College Divisions South-Western.

Benoit, W. L. (1995). Accounts, excuses, and apologies. State University of New York Press.

Benoit, W. L. (1997). Image repair discourse and crisis communication. Public Relations Review, 23(2), 177-186. https://doi.org/10.1016/S0363-8111(97)90023-0

Bowen, M., Freidank, J., Wannow, S., \& Cavallone, M. (2017). Effect of perceived crisis response on consumers' behavioral intentions during a company scandal - an intercultural perspective. Journal of International Management, 24(3), 222-237. https://doi.org/10.1016/j.intman.2017.12.001

Bowen, S. A., \& Zheng, Y. (2015). Auto recall crisis, framing, and ethical response: Toyota's missteps. Public Relations Review, 41(1), 40-49. https://doi.org/10.1016/j.pubrev.2014.10.017

Bradford, J. L., \& Garrett, D. E. (1995). The effectiveness of corporate communicative responses to accusations of unethical 
behaviour. Journal of Business Ethics, 14(11), 875-892. https://doi.org/10.1007/BF00882067

Brown, K. A., \& Ki, E. J. (2013). Developing a valid and reliable measure of organizational crisis responsibility. Journalism \& Mass Communication Quarterly, 90, 363-384. https:/doi. org/10.1177/1077699013482911

Brown, K. A., \& White, C. L. (2010). Organization-public relationships and crisis response strategies: impact on attribution of responsibility. Journal of Public Relations Research, 23(1), 75-92. https://doi.org/10.1080/1062726X.2010.504792

Bundy, J., \& Pfarrer, M. D. (2015). A burden of responsibility: The role of social approval at the onset of a crisis. Academy of Management Review, 40(3), 345-369.

https://doi.org/10.5465/amr.2013.0027

Bundy, J., Pfarrer, M. D., Short, C. E. \& Coombs, W. T. (2017). Crises and crisis management: integration, interpretation, and research development. Journal of Management, 12(1), 1492063-1668003.

https://doi.org/10.1177/0149206316680030

Cheng, Y., \& Lee, C.-J. (2019). Online crisis communication in a post-truth Chinese society: Evidence from interdisciplinary literature. Public Relations Review, 101826. https://doi.org/10.1016/j.pubrev.2019.101826

Chun-ju, F., Hung-Baesecke, \& Chen, Y. (2013). The effects of organization-public relationship types and quality on crisis attributes. In K. Sriramesh, A. Zerfass, \& J. Kim (Ed.), Public relations and communication management current trends and emerging topics (1st ed.). Routledge.

https://www.taylorfrancis.com/books/e/9780203079256

Claeys, A. S., \& Cauberghe, V. (2014). What makes crisis response strategies work? The impact of crisis involvement and message framing. Journal of Business Research, 67(2), 182189. https://doi.org/10.1016/j.jbusres.2012.10.005

Claeys, A., \& Coombs, W. (2020). Organizational crisis communication: suboptimal crisis response selection decisions and behavioral economics. Communication Theory, 30(3), 290-309. https://doi.org/10.1093/ct/qtz002

Coombs, W. T. (1995). Choosing the right words: The development of guidelines for the selection of the "appropriate" crisis response strategies. Management Communication Quarterly, 8, 447-476. https://doi.org/10.1177/0893318995008004003

Coombs, T. W., \& Holladay, S. J. (2006). Unpacking the halo effect: reputation and crisis management. Journal of Communication Management, 10(2), 123-137. https://doi.org/10.1108/13632540610664698

Coombs, W., \& Holladay, S. (2002). Helping crisis managers protect reputational assets. Management Communication Quarterly, 16(2), 165-186. https://doi.org/10.1177/089331802237233

Coombs, W. T. (2006a). Crisis management: A communicative approach. In C. H. Botan, \& V. Hazleton (Eds.), Public relations theory II. Lawrence Erlbaum.

Coombs, W. T. (2006b). The protective powers of crisis response strategies. Journal of Promotion Management, 12(3-4), 241260. https://doi.org/10.1300/J057v12n03_13

Coombs, W. T. (2007a). Protecting organization reputations during a crisis: the development and application of situational crisis communication theory. Corporate Reputation Review, 10(3), 163-176. https://doi.org/10.1057/palgrave.crr.1550049

Coombs, W. T. (2007b). Ongoing crisis communication: Planning, managing, and responding ( $2^{\text {nd }} \mathrm{ed}$.). SAGE.

Coombs, W. T. (2015). The value of communication during a crisis: Insights from strategic communication research. Business Horizons, 58(2), 141-148.

https://doi.org/10.1016/j.bushor.2014.10.003
Coombs, W. T., \& Holladay, J. S. (2012). The paracrisis: The challenges created by publicly managing crisis prevention. Public Relations Review, 38(3), 408-415.

https://doi.org/10.1016/j.pubrev.2012.04.004

Coombs, W. T., \& Jean, S. (2014). How publics react to crisis communication efforts. Journal of Communication Management, 18(1), 40-57.

https://doi.org/10.1108/JCOM-03-2013-0015

Coombs, W. T., \& Laufer, D. (2018). Global crisis managementcurrent research and future directions. Journal of International Management, 24(3), 199-203.

https://doi.org/10.1016/j.intman.2017.12.003

Coombs, W. T., \& Tachkova, E. R. (2018). Scansis as a unique crisis type: theoretical and practical implications. Journal of Communication Management, 23(1).

https://doi.org/10.1108/JCOM-08-2018-0078

Coombs, W. T., Frandsen, F., Holladay, S. J., \& Johansen, W. (2010). Why a concern for apologia and crisis communication? Corporate Communications: An International Journal, 15(4), 337-349. https://doi.org/10.1108/13563281011085466

Coombs, W. T. \& Holladay, S. J. (2001). An extended examination of the crisis situation: A fusion of the relational management and symbolic approaches. Journal of Public Relations Research, 13, 321-340. https://doi.org/10.1207/S1532754XJPRR1304_03

Coombs, W. T., \& Holladay, S. J. (2008). Comparing apology to equivalent crisis response strategies: clarifying apology's role and value in crisis communication. Public Relations Review, 34(3), 252-257. https://doi.org/10.1016/j.pubrev.2008.04.001

Coombs, W. T., \& Holladay, S. J. (1996). Communication and attributions in a crisis: an experimental study in crisis communication. Journal of Public Relations Research, 8(4), 279-295. https://doi.org/10.1207/s1532754xjprr0804_04

Custance, P., Walley, K., \& Jiang, D. (2012). Crisis brand management in emerging markets. Marketing Intelligence \& Planning, 30(1), 18-32. https://doi.org/10.1108/02634501211193895

Cwalina, W., \& Falkowski, A. (2018). Crisis management: government strategy in framing reform proposals and communications. Journal of Political Marketing, 17(2), 122-136. https://doi.org/10.1080/15377857.2018.1447754

Dawar, N., \& Lei, J. (2009). Brand crises: the role of brand familiarity and crisis relevance in determining the impact on brand evaluations. Journal of Business Research, 62(4), 509-516. https://doi.org/10.1016/j.jbusres.2008.02.001

De Blasio, A., \& Veale, R. (2009). Why say sorry? Influencing consumer perceptions post organizational crises. Australasian Marketing Journal (AMJ), 17(2), 75-83. https://doi.org/10.1016/j.ausmj.2009.05.007

DiStaso, M. W., Vafeiadis, M., \& Amaral, C. (2015). Managing a health crisis on Facebook: How the response strategies of apology, sympathy, and information influence public relations. Public Relations Review, 41(2), 222-231. https://doi.org/10.1016/j.pubrev.2014.11.014

Do, B., Nham, T., \& Nguyen, T. (2019). An investigation the main internal brand crisis antecedents. Business: Theory and Practice, 20, 234-247. https://doi.org/10.3846/btp.2019.23

Dutta, S., \& Pullig, C. (2011). Effectiveness of corporate responses to brand crises: The role of crisis type and response strategies. Journal of Business Research, 64(12), 1281-1287. https://doi.org/10.1016/j.jbusres.2011.01.013

Einwiller, S., \& Johar, G. V. (2007, May 22-25). Preventing damage from accusations - the case of WalMart. In the Paper Presented at the 36th Annual European Marketing Academy Conference. Reykjavik, Iceland. 
Euromonitor International, E. (2019). Understanding the Techsumer: how technology is changing global consumption. In Market Research Report, Euromonitor. https://www.euromonitor.com/understanding-the-techsumer-how-technology-ischanging- global-consumption/report

Gistri, G., Corciolani, M., \& Pace, S. (2019). Does the perception of incongruence hurt more? Customers' responses to CSR crises affecting the main reputation dimension of a company. Journal of Marketing Management, 35(7-8), 605-633. https://doi.org/10.1080/0267257X.2019.1580761

Grundy, M., \& Moxon, R. (2013). The effectiveness of airline crisis management on brand protection: A case study of British Airways. Journal of Air Transport Management, 28, 55-61. https://doi.org/10.1016/j.jairtraman.2012.12.011

Gumgum. (2018). Brandrx: the new brand safety crisis. https://gumgum.com/guides/the-new-brand-safety-crisis

Hansen, N., Kupfer, A.-K., \& Hennig-Thurau, T. (2018). Brand crises in the digital age: The short- and long-term effects of social media firestorms on consumers and brands. International Journal of Research in Marketing, 35(4), 557-574. https://doi.org/10.1016/j.ijresmar.2018.08.001

Hearit, K. M. (1997). On the use of transcendence as an apologia strategy: The case of Johnson controls and its fetal protection policy. Public Relations Review, 23(3), 217-231. https://doi.org/10.1016/S0363-8111(97)90033-3

Hearit, K. M. (2006). Crisis management by apology: Corporate response to allegations of wrong doing. Lawrence Erlbaum Associates, Publishers. https://doi.org/10.4324/9781410615596

Hegner, S. M., Beldad, A. D., \& Kraesgenberg, A.-L. (2016). The impact of crisis response strategy, crisis type, and corporate social responsibility on post-crisis consumer trust and purchase intention. Corporate Reputation Review, 19(4), 357-370. https://doi.org/10.1057/s41299-016-0007-y

Hewett, K., \& Lemon, L. (2019). A process view of the role of integrated marketing communications during brand crises. Qualitative Market Research, 22(3), 497-524. https://doi.org/10.1108/QMR-10-2016-0097

Huang, Y.-H. (2006). Crisis situations, communication strategies, and media coverage. Communication Research, 33(3), 180-205. https://doi.org/10.1177/0093650206287077

Huang, Y.-H. (2008). Trust and relational commitment in corporate crises: the effects of crisis communicative strategy and form of crisis response. Journal of Public Relations Research, 20(3), 297327. https://doi.org/10.1080/10627260801962830

Ihlen, Ø. (2002). Defending the Mercedes A-Class: combining and changing crisis-response strategies. Journal of Public Relations Research, 14(3), 185-206. https://doi.org/10.1207/S1532754XJPRR1403_2

Ismail, N. B. M., Pagulayan, M. A., Francia, C. M. A., \& Pang, A. (2018). Communicating in the post-truth era: Analyses of crisis response strategies of Presidents Donald Trump and Rodrigo Duterte. Journal of Public Affairs, e1883.

https://doi.org/10.1002/pa.1883

Iyengar, S. (1991). Is anyone responsible? How television frames political issues. University of Chicago Press.

https://doi.org/10.7208/chicago/9780226388533.001.0001

James, E. H., Wooten, L. P., \& Dushek, K. (2011). Crisis management: informing a new leadership research agenda. The Academy of Management Annals, 5(1), 455-493.

https://doi.org/10.1080/19416520.2011.589594

Jiménez, R., Redondo, B., Molina, R., Martínez-Domingo, M. Á., Hernández-Andrés, J., \& Vera, J. (2020). Short-term effects of text-background color combinations on the dynamics of the accommodative response. Vision Research, 166, 33-42.

https://doi.org/10.1016/j.visres.2019.11.006
Jin, Y. (2013). Examining publics' crisis responses according to different shades of anger and sympathy. Journal of Public Relations Research, 26(1), 79-101.

https://doi.org/10.1080/1062726X.2013.848143

Johar, G. V., Birk, M. M., \& Einwiller, S. A. (2010). How to save your brand in the face of crisis. MIT Sloan Management Review, Summer, 57-64.

Jung, O J., \& Baeck, S. (2016). What drives consumer's responses to brand crisis? The moderating roles of brand associations and brand-customer relationship strength. Journal of Product \& Brand Management, 25(6), 550-567.

https://doi.org/10.1108/JPBM-10-2014-0725

Kahn, W. A., Barton, M. A., \& Fellows, S. (2013). Organizational crises and the disturbance of relational systems. Academy of Management Review, 38(3), 377-396.

https://doi.org/10.5465/amr.2011.0363

Kim, S., \& Atkinson, L. J. (2014). Responses toward corporate crisis and corporate advertising. Journal of Promotion Management, 20(5), 647-665.

https://doi.org/10.1080/10496491.2014.946201

Kim, S., \& Sung, K. H. (2013). Revisiting the effectiveness of base crisis response strategies in comparison of reputation management crisis responses. Journal of Public Relations Research, 26(1), 62-78. https://doi.org/10.1080/1062726X.2013.795867

Kim, S., Zhang, X. A., \& Zhang, B. W. (2016). Self-mocking crisis strategy on social media: Focusing on Alibaba chairman Jack Ma in China. Public Relations Review, 42(5), 903-912. https:// doi.org/10.1016/j.pubrev.2016.10.004

Kim, Y., \& Park, H. (2017). Is there Still a PR Problem Online? Exploring the effects of different sources and crisis response strategies in online crisis communication via social media. Corporate Reputation Review, 20(1), 76-104. https://doi. org/10.1057/s41299-017-0016-5

Kotler, P., Armstrong, G., \& Opresnik, M. O. (2018). Principles of marketing (17e. Global ed.). Pearson.

Kriyantono, R., \& McKenna, B. (2020). Crisis response vs crisis cluster: a test of situational crisis communication theory on crisis with two crisis clusters. Indonesian Public Relations, 35(1). https://doi.org/10.17576/JKMJC-2019-3501-15

Kumar, M., Parsad, C., Bamel, U., Prashar, S., \& Parashar, A. (2019). Influence of pre-crisis reputation and COO on diminishing a product-harm crisis. International Journal of Organizational Analysis, 28(4), 857-872.

https://doi.org/10.1108/IJOA-08-2019-1852

Lamin, A., \& Zaheer, S. (2012). Wall Street vs. Main Street: firm strategies for defending legitimacy and their impact on different stakeholders. Organization Science, 23(1), 47-66. https://doi.org/10.1287/orsc.1100.0631

Lange, D., \& Washburn, N. T. (2012). Understanding attributions of corporate social irresponsibility. The Academy of Management Review, 37(2), 300-326.

https://doi.org/10.5465/amr.2010.0522

Laufer, D., Garrett, T. C., \& Ning, B. (2017). The moderating role of power distance on the reaction of consumers to the CEO as a spokesperson during a product harm crisis: insights from China and South Korea. Journal of International Management, 24(3), 215-221. https://doi.org/10.1016/j.intman.2017.12.002

Lee, S. Y., \& Atkinson, L. (2019). Never easy to say "sorry": Exploring the interplay of crisis involvement, brand image, and message appeal in developing effective corporate apologies. Public Relations Review, 45(1), 178-188.

https://doi.org/10.1016/j.pubrev.2018.12.007 
Lee, S. Y., Sung, Y. H., Choi, D., \& Kim, D. H. (2019). Surviving a crisis: how crisis type and psychological distance can inform corporate crisis responses. Journal of Business Ethics, 168, 795-811. https://doi.org/10.1007/s10551-019-04233-5

Li, Y., Yang, K., Chen, J., Gupta, S., \& Ning, F. (2019). Can an apology change after-crisis user attitude? The role of social media in online crisis management. Information Technology \& People, 32(4), 802-827. https://doi.org/10.1108/ITP-03-2017-0103

Lin, C.-P., Chen, S.-C., Chiu, C.-K., \& Lee, W.-Y. (2011). Understanding purchase intention during product-harm crises: moderating effects of perceived corporate ability and corporate social responsibility. Journal of Business Ethics, 102(3), 455-471. https://doi.org/10.1007/s10551-011-0824-y

Liu, B., Kim, H., \& Pennington-Gray, L. (2015). Responding to the bed bug crisis in social media. International Journal of Hospitality Management, 47, 76-84. https://doi.org/10.1016/j.ijhm.2015.03.005

Liu, B., Pennington-Gray, L., \& Krieger, J. (2016). Tourism crisis management: Can the extended parallel process model be used to understand crisis responses in the cruise industry? Tourism Management, 55, 310-321.

https://doi.org/10.1016/j.tourman.2016.02.021

Liu, X., Lischka, H. M., \& Kenning, P. (2018). Asymmetric cognitive, emotional and behavioural effects of values-related and performance-related negative brand publicity Journal of Product \& Brand Management, 27(2), 128-145. https://doi.org/10.1108/JPBM-11-2016-1351

Ma, L., \& Zhan, M. (Monica). (2016). Effects of attributed responsibility and response strategies on organizational reputation: A meta-analysis of situational crisis communication theory research. Journal of Public Relations Research, 28(2), 102-119. https://doi.org/10.1080/1062726X.2016.1166367

Massey, J. E., \& Larsen, J. P. (2006). Crisis management in real time. Journal of Promotion Management, 12(3-4), 63-97. https://doi.org/10.1300/J057v12n03_06

Miller, A. N., \& Littlefield, R. S. (2010). Product recalls and organizational learning: ConAgra's responses to the peanut butter and pot pie crises. Public Relations Review, 36(4), 361-366. https://doi.org/10.1016/j.pubrev.2010.06.001

Nikulina, V., Simon, D., Ny, H., \& Baumann, H. (2019). Contextadapted urban planning for rapid transitioning of personal mobility towards sustainability: a systematic literature review. Sustainability, 11(4), 1007. https://doi.org/10.3390/su11041007

Okumus, F., \& Karamustafa, K. (2005). Impact of an economic crisis: Evidence from Turkey. Annals of Tourism Research, 32(4), 942-961. https://doi.org/10.1016/j.annals.2005.04.001

Park, H. (2017). Exploring effective crisis response strategies. Public Relations Review, 43(1), 190-192. https://doi.org/10.1016/j.pubrev.2016.12.001

Pearce, J. A., \& Michael, S. C. (2006). Strategies to prevent economic recessions from causing business failure. Business $\mathrm{Ho}-$ rizons, 49(3), 201-209.

https://doi.org/10.1016/j.bushor.2005.08.008

Pfarrer, M. D., Decelles, K. A., Smith, K. G., \& Taylor, M. S. (2008). After the fall: reintegrating the corrupt organization. Academy of Management Review, 33(3), 730-749. https://doi.org/10.5465/amr.2008.32465757

Pickering, C., Grignon, J., Steven, R., Guitart, D., \& Byrne, J. (2015). Publishing not perishing: How research students transition from novice to knowledgeable using systematic quantitative literature reviews. Studies in Higher Education, 40(10), 1756-1769. https://doi.org/10.1080/03075079.2014.914907
Richards Jr O., Wilson, C., Boyle, K., \& Mower, J. (2017). A knockout to the NFL's reputation?: A case study of the NFL's crisis communications strategies in response to the Ray Rice scandal. Public Relations Review, 43(3), 615-623.

https://doi.org/10.1016/j.pubrev.2017.02.015

Rouvaki, C., Assiouras, I., \& Siomkos, G. (2014). A predictive model for affective, cognitive and behavioral consumers' reactions to product-harm crises: applying product involvement, product type and crisis response strategies. Ideas in Marketing: Finding the New and Polishing the Old, 564-564. https://doi.org/10.1007/978-3-319-10951-0_202

Sano, K., \& Sano, H. (2019). The effect of different crisis communication channels. Annals of Tourism Research, 79, 102804. https://doi.org/10.1016/j.annals.2019.102804

Sawalha, I. (2019). After the crisis: repairing a corporate image. Journal of Business Strategy (ahead-of-print).

https://doi.org/10.1108/JBS-04-2019-0075

Semerciöz, F., Pehlivan, Ç., Sözüer, A., \& Mert, A. (2015). Crisis management practices and strategic responses through customer loyalty and price strategy in hard times: evidence from fine-dining restaurants. Procedia - Social and Behavioral Sciences, 207, 149-156. https://doi.org/10.1016/j.sbspro.2015.10.164

Shim, K., \& Yang, S.-U. (2016). The effect of bad reputation: The occurrence of crisis, corporate social responsibility, and perceptions of hypocrisy and attitudes toward a company. Public Relations Review, 42(1), 68-78.

https://doi.org/10.1016/j.pubrev.2015.11.009

Singh, J., Crisafulli, B., \& Quamina, L. T. (2019). Corporate image at stake: The impact of crises and response strategies on consumer perceptions of corporate brand alliances. Journal of Business Research, 117, 839-849.

https://doi.org/10.1016/j.jbusres.2019.01.014

Singh, J., Crisafulli, B., Quamina, L. T., \& Xue, M. T. (2020). “To trust or not to trust": The impact of social media influencers on the reputation of corporate brands in crisis. Journal of Business Research, 119, 464-480.

https://doi.org/10.1016/j.jbusres.2020.03.039

Siomkos, G., Triantafillidou, A., Vassilikopoulou, A., \& Tsiamis, I. (2010). Opportunities and threats for competitors in product-harm crises. Marketing Intelligence \& Planning, 28(6), 770-791. https://doi.org/10.1108/02634501011078156

Sohn, Y. J., \& Lariscy, R. W. (2015). A "buffer" or "boomerang?" - The role of corporate reputation in bad times. Communication Research, 42, 237-259.

https://doi.org/10.1177/0093650212466891

Souiden, N., \& Pons, F. (2009). Product recall crisis management: the impact on manufacturer's image, consumer loyalty and purchase intention. Journal of Product \& Brand Management, 18(2), 106-114. https://doi.org/10.1108/10610420910949004

Standop, D., \& Grunwald, G. (2009). How to solve product-harm crises in retailing? International Journal of Retail \& Distribution Management, 37(11), 915-932.

https://doi.org/10.1108/09590550910999352

Su, L., Stepchenkova, S., \& Kirilenko, A. P. (2019). Online public response to a service failure incident: Implications for crisis communications. Tourism Management, 73, 1-12. https://doi.org/10.1016/j.tourman.2019.01.011

Vafeiadis, M., Bortree, D. S., Buckley, C., Diddi, P., \& Xiao, A. (2019). Refuting fake news on social media: nonprofits, crisis response strategies and issue involvement. Journal of Product \& Brand Management, 29(2), 209-222.

https://doi.org/10.1108/JPBM-12-2018-2146 
Vanhamme, J., Swaen, V., Berens, G., \& Janssen, C. (2015). Playing with fire: Aggravating and buffering effects of ex ante CSR communication campaigns for companies facing allegations of social irresponsibility. Marketing Letters, 26(4), 565-578. https://doi.org/10.1007/s11002-014-9290-5

Vassilikopoulou, A., Siomkos, G., Chatzipanagiotou, K., \& Pantouvakis, A. (2009). Product-harm crisis management: Time heals all wounds? Journal of Retailing and Consumer Services, 16(3), 174-180.

https://doi.org/10.1016/j.jretconser.2008.11.011

Wang, J., Anne, M., \& McLean, G. N. (2015). Understanding crisis and crisis management: an Indian perspective. Human Resource Development International, 19(3), 192-208. https://doi.org/10.1080/13678868.2015.1116242

Wang, Y., \& Laufer, D. (2019). How does crisis management in China differ from the West?: A review of the literature and directions for future research. Journal of International Management, 26(1), 100708.

https://doi.org/10.1016/j.intman.2019.100708
Ware, B. L., \& Linkugel, W. A. (1973). They spoke in defense of themselves: On the generic criticism of apologia. Quarterly Journal of Speech, 59(3), 273-283.

https://doi.org/10.1080/00335637309383176

Weiner, B. (1985). Spontaneous causal search. Psychological Bulletin, 97(1), 74-84. https://doi.org/10.1037/0033-2909.97.1.74

Xu, K., \& Li, W. (2012). An ethical stakeholder approach to crisis communication: a case study of Foxconn's 2010 employee suicide crisis. Journal of Business Ethics, 117(2), 371-386. https://doi.org/10.1007/s10551-012-1522-0

Zavyalova, A., Pfarrer M. D., Reger R. K., \& Shapiro D. L. (2012). Managing the message: the effects of firm actions and industry spill-overs on media coverage following wrongdoing. Academy of Management Journal, 55(5), 1079-1101. https://doi.org/10.5465/amj.2010.0608

Zhu, L., Anagondahalli, D., \& Zhang, A. (2017). Social media and culture in crisis communication: McDonald's and KFC crises management in China. Public Relations Review, 43(3), 487-492. https://doi.org/10.1016/j.pubrev.2017.03.006

\section{APPENDIX}

Low level

of organisational efforts/ responsibility

High level of organisational efforts/ responsibility

\section{PRIMARY STRATEGY}

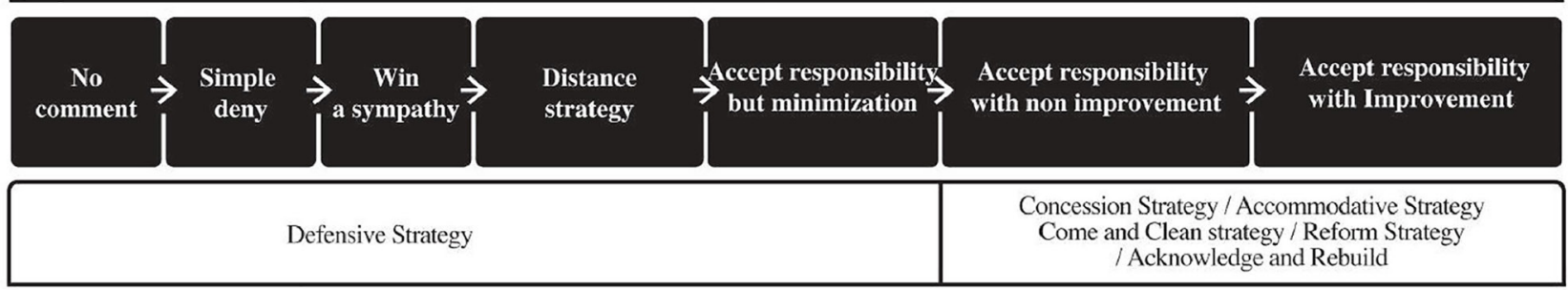

\begin{tabular}{|c|c|c|c|c|c|c|c|c|c|c|c|c|c|c|c|}
\hline \multicolumn{4}{|c|}{ Avoiding / Refuse Strategy } & \multicolumn{6}{|c|}{$\begin{array}{l}\text { Fighting / Refuse strategy } \\
\text { / Reduce offensiveness strategy }\end{array}$} & & & & \multicolumn{3}{|c|}{$\begin{array}{l}\text { Corrective strategy /Conciliation } \\
/ \text { Compromising strategy }\end{array}$} \\
\hline No comment & Deny & \multicolumn{2}{|c|}{$\begin{array}{l}\text { Suffering strategy } \\
\text { /Rebutal strategy }\end{array}$} & \begin{tabular}{|c|} 
Differentia \\
-tion
\end{tabular} & Scapegoat & $\begin{array}{l}\text { Attack } \\
\text { accuser }\end{array}$ & \multicolumn{3}{|c|}{$\begin{array}{l}\text { Diminishment Strategy/ } \\
\text { Yes.... but strategy }\end{array}$} & \multicolumn{3}{|c|}{ Organisational casual response } & \multicolumn{3}{|c|}{ Rebuild strategy } \\
\hline $\begin{array}{l}\text { Non-existence } \\
\text { Strategy }\end{array}$ & Deny the defect & Provocation & Defesibility & $\begin{array}{c}\text { Disscriation } \\
\text { Opinion } \\
\text { knounlededge }\end{array}$ & Inoculation & & $\begin{array}{l}\text { Individual } \\
\text { casual } \\
\text { response }\end{array}$ & $\begin{array}{c}\text { Accident } \\
\text { - essence } \\
\text { dissociation }\end{array}$ & $\begin{array}{c}\text { Indivicial } \\
\text { group } \\
\text { responsibility }\end{array}$ & Acknowledge & Regret & Apology & $\begin{array}{c}\text { Involuntary } \\
\text { recall }\end{array}$ & $\begin{array}{c}\text { Voluntary } \\
\text { recall }\end{array}$ & $\begin{array}{l}\text { Super } \\
\text { cffort }\end{array}$ \\
\hline \multirow[t]{3}{*}{ No response } & Simple deny & & & $\begin{array}{c}\text { Ceremonial } \\
\text { actions }\end{array}$ & $\begin{array}{l}\text { Vilify the } \\
\text { accuser }\end{array}$ & & \multicolumn{2}{|c|}{ Minimization } & $\begin{array}{c}\text { Individual } \\
\text { group } \\
\text { responsibility }\end{array}$ & Information & Sympathy & & $\begin{array}{c}\text { Forced } \\
\text { compliance }\end{array}$ & $\begin{array}{c}\text { Voluntary } \\
\text { compliance }\end{array}$ & $\begin{array}{c}\text { Add-value } \\
\text { action }\end{array}$ \\
\hline & & & & Defiance & & & Excuse & Justification & $\begin{array}{l}\text { Trancen } \\
\text { dence }\end{array}$ & Technical actions & & & & \multicolumn{2}{|c|}{ Compensation } \\
\hline & & & & Decoupling & & & & & & & & & & \multicolumn{2}{|c|}{ Offer Amends } \\
\hline
\end{tabular}

\section{SECONDARY STRATEGY}

Rolsterino / Inoratiatino Strateov / Polish the halo / Proactive

Figure 2. Research result - brand crisis response strategies continuum (source: author's analysis) 